\title{
The Classical Fissociation.
}

The objects of the Classical Association are to promote the development and maintain the well-being of classical studies, and in particular (a) to impress upon public opinion the claims of such studies to an eminent place in the national scheme of education; $(b)$ to improve the practice of classical teaching; $(c)$ to encourage investigation and call attention to new discoveries; (d) to create opportunities for intercourse among lovers of classical learning.

Membership of the Association is open to men and women alike. The annual subscription is 5s. (life composition, $\ell_{5} 5^{\mathrm{s}}$.). Members receive a copy of the annual Proceedings of the Association. They may also obtain the Classical Review and Classical Quarterly at reduced prices, though the reduction cannot be guaranteed unless the subscription is paid before January 3 Ist in each year. Greece and Rome may be obtained for an annual subscription of $103.6 \mathrm{~d}$.

Applications or membership should be addressed to the Hon. Treasurer of the Association (J. S. Shields, M.A., Queen Mary's School, Basingstoke, Hants.). Inquiries should be addressed to either of the Hon. Secretaries of the Association, (T. W. Melluish, M.A., Bec School, London, S.W. 1 7, and Professor L. J. D. Richardson, M.A., University College, Cardiff), or to the Hon. Secretary of any one of the Local Branches, viz., Aberystwyth, Bedford, Birmingham, Bristol, Cambridge, Cardiff, East Anglia, Hull, Kent, Leeds, Leicester, Liverpool, London, Manchester, Northumberland and Durham, North Wales, Nottingham, Oxford, Reading, Sheffield, Shrewsbury, Southampton, South Western, Swansea, Taunton and West Somerset.

\section{THE ANGLO-HELLENIC LEAGUE}

The Anglo-Hellenic League was founded in 1913, and its aims are to strengthen the ties between Britain and Greece and to promote friendship between the British and Hellenic races by spreading information, encouraging travel, and improving social, commercial and international relations.

The League is an independent, non-governmental and non-political institution.

H.R.H. the Duchess of Kent has accepted the office of President and Chief Patron of the League, which became vacant on the lamented death of her husband. The Chairman of its Executive Committee is Admiral Sir Howard Kelly, G.B.E., K.C.B., C.M.G., M.V.O.

The events of the war and the Anglo-Greek alliance have widened the opportunities for service and activity of the Anglo-Hellenic League. All those who are interested in Anglo-Hellenic friendship, in the cause of Greece, are cordially invited to apply for membership of the League.

Full particulars can be obtained on application, from the Honorary Secretary, Mrs. Dora Lykiardopulo, 47 Cromwell Road, S.W.7.

Contributions to the Journal should be sent to Prof. A. W. Gomme, The University, Glasgow. Books intended for review should be addressed to The Librarian, Hellenic Society, 50 Bedford Square, London, W.C. 1. All applications for advertising space in the JourNal should be addressed to The Advertisement Manager, Hellenic Society, 


\section{The Society for the Promotion of Hellenic Studies}

5O Bedford Square, London, W.G.r.

President: Professor T. B. L. Webster, F.S.A.

The Society, founded in 1879 to advance the study. of Greek language, literature, history and art, maintains conjointly with the Society for the Promotion of Roman Studies

I. A Library of some 25,000 volumes, containing many costly works and rare periodicals.

2. Large collections of classified photographs for reference and research.

3. Some 25,000 lantern slides covering the whole domain of ancient life and art.

Besides the general collection, there are sets of slides with lecture texts, and a few film strips.

Books, slides and film strips can be sent to Members by post.

Communications about books and slides should be addressed to the librarian at the above address.

By arrangement with the Society of Antiquaries the quarterly General Meetings are normally held in that Society's rooms at Burlington House, Piccadilly, W.I.

The Fournal of Hellenic Studies, recognized at home and abroad as one of the foremost periodicals in the field of classical scholarship, contains articles by leading authorities, numerous illustrations and reviews of recent books of importance to classical studies; it is at present published yearly as a single volume, which Members receive free of charge, the price to the public being $\mathcal{L}_{3}$.

The Annual Subscription to the Society is $f_{2}$. The Composition Fee for lifemembership is twenty guineas for persons over fifty years of age and thirty guineas for others. The subscription for Libraries and Student Associates is $\AA^{2}$ and $\ell^{\prime}$ respectively. There is no entrance fee.

Applications for membership or inquiries about the Society should be addressed to the Secretary at the above address.

\section{The Society for the Promotion of Roman Studies \\ 50, Bedford Square, London, W.G. I \\ President: Profrssor RONALD SYME, F.B.A.}

THE subjects to promote the study of which the Society was formed 1 are the history, archrology and art of Rome, Italy and the Roman Empire in general down to about 700 A.D. In particular, so far as its resources permit, and so far as is possible without prejudice to the wider objects with which it is concerned, the Society endeavours to encourage the study of Britain under Roman occupation by devoting space in its Journal to articles on Romano-British history and archæology.

In connexion with the Society for the Promotion of Hellenic Studies the Society maintains a joint library of works on classical antiquity, and a collection of lantern-slides and photographs. Members areentitled toborrowbooks and slides, and these can be sent to them by post. Communications about books and slides should be addressed to the Librarian at 50 Bedford Square.

Afternoon meetings for the reading and discussion of papers are held at Burlington House, Piccadilly, W.r. Numerous meetings are also held in University and other towns. Notices of all meetings are sent to members.

The Journal of Roman Studies, which is open to the contributions of both British and foreign scholars, is published by the Society now in one annual volume, and is sent post free to all members at the end of the year.

The Annual Subscription for membership of the Society is two pounds. The composition fee for life membership, is twenty guineas for persons over fifty years of age, and thirty guineas for others. Student Associates are admitted at the reduced subscription of one pound.

Persons desirous of joining the Society are asked to communicate with the Secretary at the Haverfield Library, Ashmolean Museum, Oxford. 